
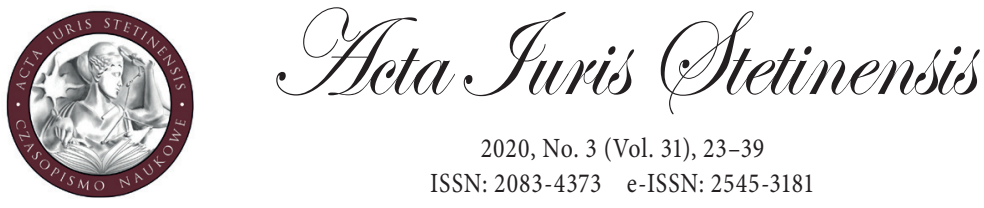

2020, No. 3 (Vol. 31), 23-39

ISSN: 2083-4373 e-ISSN: 2545-3181

DOI: $10.18276 /$ ais.2020.31-02

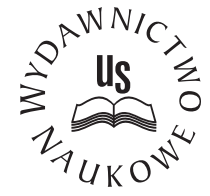

Michał Grudecki

Ph.D.

University of Silesia in Katowice, Poland

e-mail: michalgrudecki@gmail.com

ORCID ID: 0000-0002-5185-3770

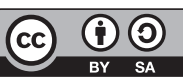

\title{
Mateusz Sajkowski
}

Student

The Pontifical University of John Paul II in Krakow, Poland

e-mail:mat.sajkowski@gmail.com

ORCID ID: 0000-0001-8915-2729

\section{Suicide from the joint perspective of canon law and Polish law}

\begin{abstract}
The purpose of this paper was to show how the ecclesiastical and secular societies protect human life against a specific danger posed by one's own hand. The authors, basing on the formal-dogmatic approach, researching literature and analysing appropriate norms of canon and Polish law, demonstrate that both canon and Polish criminal law provisions on suicide protect human life only circumstantially. In the first part, we present the issue of suicide from the point of view of moral teachings of the Catholic Church, which are a fundamental law-making factor for the ecclesiastical community. Reception of the ethical doctrine by canon law was reflected in two Codes of Canon Law, those of 1917 and 1983. In these codifications, we traced gradual reduction of prohibitions or sanctions for suicides (especially regarding right to Christian burial), which however does not refer to all self-killers, because of the need for protecting other spiritual goods (suicide attempt as irregularity in the case of receiving or exercising holy orders). In the second part, we presented the problem of suicide
\end{abstract}


in the context of Polish law, with special emphasis on the significance of human life as a legal interest subject to strong protection and as a conflict between life and dignity. We also analysed the question of the unlawfulness of suicide attempts. In the end, we point to legal measures intended to prevent this phenomenon, which is unfavourable to the society.

Keywords: suicide, moral teaching of the Church, canon law, criminal law, right to life and human dignity

\section{Introduction}

The thought of the Second Vatican Council concerning the coexistence of the Church and the State, which has found its deepest expression in the Constitution Gaudium et spes, represents a completely new opening in the field of these relations $^{1}$ - quite different from that which was still promoted as being right during the first decades of the 20th century ${ }^{2}$. It seems that it is precisely because of their concern for human beings - in spite of their separate aims - that both communities, ecclesial and secular, have a vital interest in suicidal issues and are making concrete legislative efforts to ensure the protection of these both fundamental values, that is, human existence as well as other intangible goods ${ }^{3}$.

In our presentation we will show the ways in which the mentioned communities protect the life of an individual in the Republic of Poland against a specific kind of danger - coming from its own side. We will highlight the norms that have a preventative function, deterring an individual from suicide attempts; we will as well describe the norms which protect human freedom from being influenced by others when making such a tragic decision and which are aimed at the safeguarding of spiritual goods in the form of the sacraments and sacramentals. We hypothesise that de lege lata both norms of canon law and Polish criminal law that concern suicide only circumstantially protect human life. Their closer subject of protection is other goods.

1 'The political community and the Church are, in their respective fields, independent and autonomous from each other. But both communities, though by different titles, serve the individual and social vocation of the same people', Vatican Council II, Pastoral Constitution on the Church in the Modern World Gaudium et spes, 7.12.1965, in: Groblicki, J. and Florkowski, E. (eds.), Vatican Council II. Constitutions, edicts, declarations. Polish text, Poznań 1968, No. 76.

2 See: Gasparri, P., Catholic Catechism, translated by Korzonkiewicz, J., Warszawa 2015, p. 83. The mutual relations of societates perfectae are characterised as follows: 'there is no separation between the Church and the state, nor can the state be rightly governed on the principle of separation from the Church'.

3 These intangible goods will often be differently understood in the church's and secular legal order. 
The size of this paper does not allow for a more comprehensive approach to this issue $^{4}$. Therefore, the authors do not exclude the possibility of conducting further research, which may result in the publication of a more extensive study on this highly emotional and deeply problematic practical issue.

\section{Suicide in the moral teaching of the Church}

Ancient Jewish culture, like the other civilisations of the Mediterranean basin, was not characterised by a negative approach to the phenomenon of suicide ${ }^{5}$. This is also reflected in the pages of the Old Testament. Examples of effective suicide attempts by Abimelech (see Judg 9:54) ${ }^{6}$, Samson (see Judg 16:30), Saul (see 1 Sam 31:4), Saul's armour bearer (see 1 Sam 31:5), Achitofel (see 2 Sam 17:23), Zimri (see 1 Kgs 16:18) and Razis (see 2 Macc, 14:43-46) not only weren't stigmatised by the inspired editors, but are sometimes even justified or praised as honourable or noble (especially in the face of imminent defeat in battle). The biblical descriptions in the indicated stories emphasise the tragedy of the situation in which - the characters often find themselves forced to choose between two solutions abounding in terrible consequences, or caused by the fear of a shameful or cruel death from the hands of a merciless enemy, which undoubtedly reflects the emotions that accompany a person on the threshold of deciding whether to end his/her own life.

The radically opposed opinion on this issue, which the Church will consider as its own, is represented by St. Augustine of Hippo, an early Christian philosopher and theologian. The treatise De civitate Dei, considered by experts as the most prominent elucidation of its author's views, is essentially based on the confrontation of customs, attitudes, or patterns of pagan civilisation with its Christian antithesis, i.e. the said new People of God. There, Doctor Gratiae takes up a clear criticism of the practice of voluntary death accepted in the Roman Empire, ${ }^{7}$ claiming: 'he who takes his own life the killer is, and is so much more guilty of killing himself than he was less guilty of in the matter for which he takes his own life. ${ }^{8}$ He cites as justification for this claim the case of Judas' suicide after betraying the Lord Jesus

4 K. Burdziak points out very aptly that: '(...) suicide is an extremely complex phenomenon, characterised by an extremely complicated structure, and at the same time - going beyond unambiguous solutions. See: Burdziak, K., Samobójstwo w prawie polskim, Warszawa 2019, p. 175.

5 See: Walton, J.H. et al., in: Chrostowski, W. (ed.), The IVP Bible background commentary: Old Testament, Warszawa 2014, p. 382.

6 Biblia Tysiąclecia - Pismo Święte Starego i Nowego Testamentu, Wyd. 5, Poznań 2012.

7 More on this topic: Hołówka, J., Etyka w działaniu, Warszawa 2001, pp. 99-102.

8 Augustine of Hippo, The City of God, Kęty 2002, p. 41 (De civ. I, 17). 
(see Matt 27:5) ${ }^{9}$. The thinker also gives a broad interpretation of the 5th commandment of the Decalogue, making it clear that it refers primarily to the one to whom it was entrusted to obey, ${ }^{10}$ which can be seen as a kind of novum - a break with the neutral evaluation of the suicidal act yet inherited from Israeli tradition.

The position of Augustinian thought has been absorbed by St. Thomas Aquinas, who in Summa theologiae - the most profound work of the scholastic era - gives arguments for the wickedness of the suicide attempt. Aquinas points out: firstly, every being ex sua natura loves itself, striving to preserve its existence; secondly, man as a social being does everything towards others, which implies that every moral misconduct also hits others; thirdly, the power over human existence is exercised by God alone, who sovereignly decides on birth or death ${ }^{11}$.

The post-conciliar teaching of the Church, as expressed in the Encyclical Evangelium vitae of John Paul II, maintains - to the fullest extent - the negative qualification of suicide, calling it 'deeply immoral' ${ }^{12}$ and also unacceptable in any situation. Although the objective evaluation of the suicidal act remains unchanged, the Magisterium, taking into account the achievements of the humanities - especially in the field of the study of the human mind - allows the subjective responsibility of the person to be mitigated or even removed ${ }^{13}$ if certain circumstances accompanying the deed will materialise, such as 'severe mental disorders, fear or serious concern of attempt, suffering or torture. ${ }^{14}$

\section{Code of Canon Law}

The first orderly compilation of canon law ${ }^{15}$ in the form of a modern code, characteristic for secular systems, was promulgated by Benedict XV by the Apostolic Constitution Providentissima Mater Ecclesia of 27 May 1917. The novelty of the Work is the abandonment of the casuistic method since individual canons are given in the form of short and concise commanding or forbidding sentences. Specific

9 'Since we rightly condemn Judas' deed, and such a verdict we proclaim, by hanging himself he not only did not atone for ... treason, but rather increased his guilt; ibidem [De civ. I, 17].

10 Ibidem, p. 45. (De civ. I, 20).

11 See: St. Thomas Aquinas, Summa theologiae, vol. 18 (Justice), translated by Bednarski, F., London 1970, p. 114 (Part II-II, Question 64, Art. 5). The motifs shown were also referred to in the book: Gasparri, P., op. cit., p. 106.

12 John Paul II, Encyclical Evangelium vitae, Poznań 1995, No. 66.

13 Ibidem.

14 Katechizm Kościoła Katolickiego, wyd. II, Poznań 2012, No. 2282.

15 Codex Iuris Canonici auctoritate Pii X Pontificis Maximi iussu digestus Benedicti Papae XV auctoritate promulgatus, 27.05.1917, Vaticanae 1961. 
regulations covering the taking one's own life have been included in various codification books, because they referred to various intangible goods protected by the Church community. These norms - copied directly from the doctrine - were at that time a practical reflection of the negative assessment of the suicidal act from a moral point of view, which was expressed in the attribution of specific legal inconveniences to the suicide, which have been described below.

\section{Deprivation of a church burial}

Canon $1239 \$ 3$ of the Pio-Benedictine Code expressis verbis statutes the right of all baptised ${ }^{16}$ to receive a Catholic burial. This specific entitlement - as E. Sztafrowski emphasises - stems from visible belonging to the Church, which gives it the value of inalienability. ${ }^{17}$ However, the same provision adds in fine a clause indicating the possibility of being deprived of this right (this stems from the use of the Latin verb privare) if someone has not shown a sign of remorse before his death. An enumerative catalogue ${ }^{18}$ of entities to be denied sepultura ecclesiastica can be found in can. $1240 \$ 1$, and among them are also those who have deliberately tried to kill themselves (see can. $1240 \$ 1,3^{\circ}$ ).

The burial ban is an ecclesial sui generis sanction with a dual punitive and educational character, since on the one hand it is intended to punish a person who has committed a crime or at least a grave sin, and on the other hand to warn the living. ${ }^{19}$ The norms, in addition to privatio sepulturae itself, impose additional burdens, such as the impossibility of celebrating Mass, even an anniversary Mass, or any other canonic service for the deceased without a burial (see can. 1241) or the inclusion on the priest who was aware of the ban and yet celebrated the burial, an excommunication latae sententiae (see can. 2339).

Commenting on the refusal to bury suicides, the canonists of that time stressed the need to prove the certaint $y^{20}$ of a suicidal act in full consciousness of mind, as

16 The term omnes baptizati should be understood in coincidence with the then Canon 1203 expressing the Church's obligation to bury fideles defuncti.

17 See: Sztafrowski, E., Miejsca i czasy święte, Warszawa 1970, p. 131.

18 By the way, it is worth mentioning that the practice of creating such lists dates back to the First Council of Braga of 561. See: Wolczko, M., Odmowa pogrzebu kościelnego. Zarys ewolucji historycznej i obowiązujące normy, in: Kruk, E. (ed.), Pochówek w prawie kanonicznym i świeckim, Kraków 2019, p. 12.

19 See: Sztafrowski, E., op. cit., p. 132.

20 See: Szwagrzyk, T., Samobójstwo i pogrzeb kościelny, "Ruch Biblijny i Liturgiczny" 1961, No. 5, p. 236. As an example of the absolute necessity of establishing the certainty of the fact of suicide, the author gave the following case study: 'if, for example, a drowned man has been found, he 
well as with complete freedom of action. ${ }^{21}$ Since the ban on a funeral is a provision limiting the inherent right of the baptised it should be interpreted strictly (see can. 19), and thus the priest, in doubtful cases - when it does not threaten to be a scandal - should decide pro reo (see can. $1240 \$ 2$ ). Moreover, it was emphasised that taking one's own life is to be direct, intentional ${ }^{22}$ and complete, it means, as T. Szwagrzyk explains, 'death should come from a suicidal act and not from some other reason. ${ }^{23}$ If the above premises do not occur, that is, self-destruction does not occur, or if a permanent (mental illness) or existing limitation in logical reasoning (desperation or exultation) ${ }^{24}$ is proved, the burial cannot be refused.

The code regulations in this matter, although they may have been regarded as strict, were often tempered by the Church. The priests had to refer to each case individually, deciding each time according to the principle of equity (aequitas canonica) and taking into account the circumstances accompanying the act and reducing its gravitas.

\section{Irregularities of ordination}

The concept of irregularitas on canonical grounds remains inextricably linked to the sacrament of Holy Orders, and thus is one of the fundamental spiritual goods of the Church community. Canon 949 of the Pio-Benedictine Code distinguishes two types of ordination - higher (maiores), which included presbyterate, diaconate, subdiaconate, as well as lower (minores), i.e. acolytes, exorcists, lectors and porters. ${ }^{25}$ The candidate, due to the specificity of his ministry and the exceptional character of his clerical condition, should be legally capable to receive ordination by fulfilling a number of requirements - including being free from irregularity, defined by $\mathrm{F}$. Bączkowicz as 'a permanent obstacle (...) which forbids one from receiving ordination directly and first of all, and subsequently also forbids use of ordination already received. ${ }^{26}$

cannot be deprived of a church burial unless it will be proved with complete certainty that we are dealing with a real suicide.

21 See: Sztafrowski, E., op. cit., p. 137.

22 See: Insadowski, H., Kościelne prawo pogrzebowe, Włocławek 1930, p. 168.

23 Szwagrzyk, T., op. cit., p. 237.

24 See: Insadowski, H., op. cit., p. 168.

25 In 1972, Paul VI, through his Apostolic Letter motu proprio Ministeria quaedam, reduced the number of degrees of ordination, leaving only three maiores: the episcopate, the presbyterate, and the diaconate.

26 Bączkowicz, F., Prawo kanoniczne. Podręcznik dla duchowieństwa, vol. II, Opole 1958, p. 104. 
The codification in force at that time divided irregularitates according to their origin - ex defectu (resulting from some objective lack, even without fault, of certain physical qualities) and ex delicto (resulting from a crime). Scholars and commentators agree that the irregularities are not punishments ${ }^{27}$ but guarantees securing the sacrament of Holy Orders, which statute the direct prohibition of receiving the ordination by a clergyman bounded by them (see can. 968), as well as indirectly prohibiting the bishop from consecration of such a candidate (see can. $973 \$ 3$ ).

Suicide attempt is indicated as irregularitas ex delicto (see can. $985,5^{\circ}$ ) equally the mutilation of yourself or someone else. Due to the criminal origins of this permanent obstacle, the construction of the so-called 'delictum frustratum' from can. $2212 \S 2$ should be used to describe it, characterised by the fact that the perpetrator, against his/her will, did not achieve an effect, which in the context of an assassination attempt on his/her own life means that 'someone has performed acts which by their nature lead to suicide and are sufficient in themselves, but death did not occur for reasons independent of (...) those acting. ${ }^{28}$

Moreover, the Code's legislature in another provision stipulates that if the victim of failed suicide belongs to a clergyman's state, then he should be suspended for the time prescribed by the Ordinary, as well as deprived of his benefits and removed from offices related to the spiritual care of the faithful (see can. $2350 \$ 2$ ).

\section{Present Canonical Regulations}

The idea of renewing ecclesiastical law in the spirit of aggiornamento was born under the pontificate of John XXIII, who in his Encyclical Ad Petri Cathedram of 1959 announced the adaptation of the Codex Iuris Canonici to today's needs. ${ }^{29}$ This work, after many years of preparation, culminated in the promulgation by John Paul II on 25 January 1983, with the help of the Apostolic Constitution Sacrae disciplinae leges, of a new codification ${ }^{30}$ - understood by the Pope himself - as a translation of the doctrine of the Second Vatican Council into the language of canons. ${ }^{31}$

The former can. 1240 - containing a catalogue of persons deprived of the right to a church burial - has been significantly modified, as in the 1977 version this

27 Ibidem, p. 105.

28 Ibidem, p. 120.

29 See: John XXIII, Encyclical Ad Petri Cathedram, "News of the Archdiocese of Warszawa" 1960, No. 1, pp. 4-5.

30 Pontificia Commissio Codici Iuris Canonici Authentice Interpretando, Codex Iuris Canonici auctoritate Ioannis Pauli PP. II promulgatus. Fontium annotatione et indice analytico-alphabetico auctus, 25.01.1983, Vaticanae 1989. Polish text in: Kodeks Prawa Kanonicznego, Poznań 2008.

31 See: introduction to Kodeks Prawa, p. 13. 
list was completely removed (deprivation was limited to those who had not shown signs of repentance before their death). ${ }^{32}$ However, in the 1980 overall project (and then in the final version), this list reappeared again, but in a heavily reduced form..$^{33}$ This provision finally constituted as can. 1184, no longer prohibits in genere the Catholic burial of suicides (especially those who are committed to the faith and the $\mathrm{Church}^{34}$ ), which the Polish Bishops' Conference (Episcopal Conference of Poland) explains by the fact that, according to the opinion of psychiatrists, they are not fully responsible for their deeds ${ }^{35}$ so it is difficult to speak of meeting the criterion of intentionality. At the same time, the 'native shepherds' strongly emphasise that a suicide who 'before suicide attempt gave a sin, should be treated as an outright sinner ${ }^{36}$ and therefore, in case of a scandal among the faithful, there are grounds for refusing the funeral under can. $1184 \$ 1,3^{\circ}$.

The John Paul II Code departs from material division of irregularities in favour of the subjective criterion. ${ }^{37}$ From that moment on, permanent obstacles preventing the acceptance of ordination, as well as their execution, are distinguished. The first ones, concerning the candidates, are included in can. 1041, and among them there is also an attempt to commit deliberate suicide (see can. 1041, $5^{\circ}$ ), which, according to M. Pastuszko, 'should be treated as a grave sin and not, for example, as committed by a mentally ill person, drunk or being a result of an unfortunate event. ${ }^{38}$

Interestingly, can. $1044 \$ 1$, which provides for irregularitates ad exercendos ordines, mentions, in the context of an unsuccessful suicide attempt, that it has to be a criminal act, so it seems that in order for a clergyman to be able to ascertain an irregularity prohibiting him from carrying out the ordinations, the general signs of

32 See: Pontificia Commissio Codici Iuris Canonici Recognoscendo, Schema canonum libri IV De Ecclesiae munere sanctificandi, pars II De locis et temporibus sacris deque culto divino, Vaticanae 1977, p. 16.

33 See: Pontificia Commissio Codici Iuris Canonici Recognoscendo, Schema Codicis Iuris Canonici, Vaticanae 1980, p. 257.

34 See: Episcopal Conference of Poland, Instrukcja liturgiczno-duszpasterska o pogrzebie i modlitwach za zmartych, 05.05.1978, in: Obrzędy pogrzebu dostosowane do zwyczajów diecezji polskich, Katowice 2011.

35 Ibidem.

36 Ibidem.

37 Such a change may result from the redefinition of the perpetrator of a canonical crime - presently it can be done by a faithful person of the Catholic Church, that is, a person baptised in it or accepted after baptism, while the previous codification referred to all the baptised (also belonging to other confessions).

38 Pastuszko, M., Nieprawidłowości i przeszkody do święceń (kanony 1040-1049), "Prawo Kanoniczne" 2007, No. 3/4, p. 152. 
a canonical offence implicite contained in can. $1321 \$ 1,1399$ and $1401,2^{\circ}$ should exist. ${ }^{39}$ It is worth adding that in further regulations the legislator introduces the provision that ignorance of permanent obstacles does not free from them (see can. 1045), and the repetition of a given deed causes the multiplication of irregularitas, which is not without significance when making a request for dispensation (see can. $1049 \$ 1)$.

\section{Suicide in Canon Law - conclusions}

Code provisions on suicide remain firmly rooted in the Church's moral doctrine which negatively addresses this issue, but taking into account - in accordance with the motto aggiornamento - the achievements of the humanities which allow for a deeper understanding of human beings and their mental condition in the modern world. Suicidal issues are perceived in canon law primarily functionally, from the perspective of specific spiritual goods, such as the sacraments (ordination) or sacramentals (funeral), which the suicidal attempt significantly affects, often causing scandal.

The ecclesiastical legislature is therefore making concrete legislative efforts to ensure that these values, which are fundamental to the church community, will be properly protected. It should also be noted that there is now an emphasis on the need, influenced by a person's personalist vision, to understand the difficult situation that led a suicidal man to make a decision that radically contradicts the self-preserving nature of people, which is clearly expressed in the abolition of the Catholic burial ban.

\section{Life and dignity of the human being as legal goods of the highest value in the Republic of Poland}

\section{Protection of human life as a unique value and its limitations}

Human life is one of the most valuable legal goods to be protected in every corner of the world. ${ }^{40}$ The uniqueness of human life lies in the fact that it offers the possibility of realising all other values that are precious to the individual, and thus

39 See: Syryjczyk, J., Sankcje w Kościele, Warszawa 2008, pp. 97-100.

40 In the Polish legal order, the source of the norm ordering public authorities to ensure the protection of human life is Article 38 of the Constitution of the Republic of Poland of 2 April 1997, Dz.U. (Journal of Laws) of 1997, no. 78 item 483 as amended. 
constitutes a great value in itself - a fundamental good of each of us. ${ }^{41}$ However, life is not only an individual value, closely related to its owners, i.e. individual persons. For it is worth emphasising that a person never lives alone, and as a social being he/ she has to take into account at least a small degree of other people's requirements concerning his/her own person. ${ }^{42}$ As A. Gubiński points out, the general public has an interest in keeping people alive because of '(...) the uniqueness of every human being, his/her family, social and friendship ties, as well as the value of each person as a creator of material or spiritual goods. ${ }^{33}$ Suicide is therefore not only an individual's tragedy, but also affects the society in which this individual is functioning. ${ }^{44}$

The protection of this good, which is at the top of the hierarchy of legal goods, may vary in intensity, as life is not an absolute value. ${ }^{45}$ It is impossible to give it such a status because, like any legal good in everyday life, it comes into conflict with other goods, for example, when an attacker is deprived of his/her life for selfdefence purpose or in case of legal abortion.

\section{Suicide as a manifestation of the autonomy of the individual based on human dignity}

Article 30 of the Constitution of the Republic of Poland confirms that the inherent and inalienable dignity of the person shall constitute a source of freedoms and rights of persons and citizens. It shall be inviolable. The respect and protection thereof shall be the obligation of public authorities. ${ }^{46}$ As M. Chmaj notes, '(...) human dignity is revealed in the consciousness of man by showing the fact that man is different from animals, and that his/her actions by which he/she achieves existential

41 Noll, P., Übergesetzliche Rechtfertigungsgründe im besonders die Einwilligung des Verletzten, Basel 1955, p. 36, 76; Kaczmarek, T., Wolność dysponowania życiem a prawo do godnej śmierci, in: Kaczmarek, T., Rozważania o przestępstwie i karze. Wybór prac z okresu 40-lecia naukowej twórczości, Warszawa 2006, p. 405.

42 Klamut, R., Aktywność obywatelska jako rodzaj aktywności społecznej - perspektywa psychologiczna, "Studia Socjologiczne" 2013, No. 1, p. 187; Kakareko, K., Samobójstwo w różnych kulturach prawnych, in: Mozgawa, M. (ed.), Samobójstwo, Warszawa 2017, p. 325.

43 Gubiński, A., Wyłączenie bezprawności czynu, Warszawa 1961, p. 80.

44 Stefaniuk, M., Samobójstwo jako zjawisko społeczne - pojęcie i rodzaje, in: Mozgawa, M. (ed.), op. cit., p. 40.

45 As T. Kaczmarek notes: ' (...) the level of this protection is usually considered to be a measure of the culture or spiritual condition of a given community', see: Kaczmarek, T., op. cit., p. 405.

46 Granat, M., Godność człowieka $z$ art. 30 Konstytucji jako wartość i norma prawna, "Państwo i Prawo" 2014, No. 8, p. 15. 
goals are not the work of instincts, but of mind and free decisions ${ }^{37}$. Dignity is an indicator of humanity. Its essence is autonomy - the right to self-determination ${ }^{48}$.

The need to respect human dignity as an absolute value, which neither the public authorities nor a third party can violate, ${ }^{49}$ requires that people be given the opportunity to decide to end their lives so that they can do so freely, consciously and in accordance with their free will. Although the decision about suicide can be judged in different ways, it should be remembered that ' (...) suicide is a manifestation of the greatest human freedom - thus it is an arch-human event, humanistic act, not existing in the animal world. ${ }^{50}$ Enabling voluntary death involves respect for human dignity, and especially its manifestation in the use of the human gift of free will and autonomy of decision. ${ }^{51}$ Establishing by the public authorities an obligation to exist against the will of an individual would be grossly contrary to this necessity. ${ }^{52}$

Therefore, in a democratic state governed by the rule of law, it is inconceivable to lay down norms prohibiting suicide attempts, let alone sanctioning linked to them. The criminalisation of attempted suicide would constitute a restriction of human dignity due to the pursuit of the absolute protection of life, which would be unacceptable since, as the Constitutional Tribunal points out, 'according to the generally accepted view, this is the only right (of course we are talking about human dignity MG's note) to which the principle of proportionality would not be applicable. ${ }^{33}$

47 Chmaj, M., Godność człowieka jako źródło jego wolności i praw, in: Chmaj, M. (ed.), Konstytucyjne wolności i prawa w Polsce. Tom I. Zasady ogólne, Kraków 2002, p. 74.

48 Burdziak, K., op. cit., p. 87.

49 See: Zoll, A., Wymiar kary w aspekcie godności człowieka, in: Godność człowieka a prawa ekonomiczne i socjalne. Księga jubileuszowa wydana w piętnasta rocznicę ustanowienia Rzecznika Praw Obywatelskich, Warszawa 2003, p. 183.

50 Grudecki, M., Wybrane prawnokarne aspekty prób samobójczych, nakłaniania do samobójstwa oraz pomocy w samobójstwie, "Wojskowy Przegląd Prawniczy" 2019, No. 2, p. 78. K. Kakareko suggests that for some people suicide '(...) is an expression of real human freedom, allows for its realization', see: Kakareko, K., op. cit., p. 322. See also: Stefaniuk, M., op. cit., p. 13.

51 See: Kijaczko, S., Konstruktywny i niekonstruktywny potencjat samobójstwa, in: Mozgawa, M. (ed.), op. cit., p. 366; Szeroczyńska, M., Eutanazja i wspomagane samobójstwo na świecie. Studium prawnoporównawcze, Kraków 2004, p. 117.

52 Glaser, S., Zabójstwo na żądanie, Warszawa 1936, p. 47. It is worth recalling at this point the reflections of M. Płatek: 'The life of an individual has therefore a utilitarian meaning. Human life - to whom does it belong then? This question opens up a dialogue, a dilemma and the tragedy of an individual's own will towards the requirement of obedience to the authorities', see: Płatek, M., Prawna natura samobójstwa. Od anomii po autonomię, in: Mozgawa, M. (ed.), op. cit., p. 228.

53 Judgment of the Constitutional Tribunal of 5 March 2003, K 7/01, Legalis No. 56028. As M. Płatek points out, 'releasing a suicide from criminal responsibility may have been associated with an increase in social sensitivity, and over time also with the development of human rights. This, by changing the power of authority over the individual, has brought to the forefront the dignity of 


\section{Suicide as an attack on human dignity}

Of course, we can also distinguish an opinion different than the one presented above, according to which suicide violates human dignity without being an expression of the autonomy of the person deriving from that dignity. On the basis of this theory, self-destruction is considered a degradation of humanity, a destruction of one's own personality, which is the unity of body and spirit. ${ }^{54}$ Dignity is inalienable, and by depriving oneself of life, a person prevents the realisation of this dignity. In this way the person destroys his/her own individuality, makes it impossible to achieve the goal he/she has set. ${ }^{55}$ Dignity, as K. Complak points out, has a defensive character and protects '(...) human beings from violating what is most human in them. ${ }^{36}$ What can be more human in a human being than his/her right to life - the uniqueness and exceptionality of the existence of each of us, which is an opportunity to realise all other values?

Should suicide in this sense of dignity constitute a forbidden act? Perhaps the conclusion will be the same as when accepting the opposite judgement, which sees the possibility of a suicide attempt as an expression of respect for human autonomy.

For a person who decides to shorten his/her life, not a sanction for breaking the ban but the need to continue to exist is the worst that can happen to him/her. ${ }^{57}$ A suicidal person feels a mental pain that cannot be solved and finds himself/herself in a state of hopelessness and helplessness, from which he/she sees the only way to escape is in death..$^{58}$ As S. Kijaczko points out, 'if a person does not consider his/ her life as valuable, if he/she is not convinced that 'the most important aspects of life are appropriate for him/her', nothing can contribute to improving its quality' ${ }^{39}$. It is therefore inhuman to punish this one who is experiencing a personal tragedy, sometimes resulting from the disintegration of the social groups in which he/she

the human being freed from the relationship with external sovereignty (...)', see: Płatek, M., op. cit., p. 235.

54 See Burdziak, K., op. cit., pp. 94-95.

Complak, K., O prawidłowe pojmowanie godności osoby ludzkiej w porządku RP, in: Banaszak, B. and Preisner, A. (eds.), Prawa i wolności obywatelskie w Konstytucji RP, Warszawa 2002, p. 66.

Ibidem, p. 68.

57 Grudecki, M., op. cit., p. 63.

58 Stefaniuk, M., op. cit., p. 29.

59 Kijaczko, S., op. cit., p. 368. As K. Burdziak points out, 'given the mental state of an individual before a suicide attempt, it is impossible to expect that a possible legal norm prohibiting suicide could directly influence the behaviour of a suicide man in any way', see: Burdziak, K., op. cit., p. 104. 
functions (family, work, friends) or the entire society, a serious illness or the transformation of the value system. ${ }^{60}$

In view of the above, it is worth emphasising that an effort to subject the postulate of introducing a ban on suicide attempts to the proportionality test under Article 31 section 3 of the Constitution of the Republic of Poland would have a negative effect already when checking the usefulness of establishing such a standard. A ban on suicide attempts, even if combined with a criminal law, cannot be an effective tool in combating this unfavourable social phenomenon. Such a sanctioned standard could not effectively influence the subject's behaviour and motivate him/her to the desired behaviour. In fact, the opposite would be true, since, as A. Wąsek suggests, '(...) the punishment of attempted suicide could mobilise desperate people to seek more effective methods of depriving themselves of their lives. ${ }^{61}$ In some cases, these could be dangerous methods for other people (for example, subjecting oneself to carbon monoxide gas poisoning or throwing oneself under a car). We may also wonder whether criminalising suicide attempts would not increase interest in this type of behaviour according to the reactance theor $y^{62}$. To put it simply, 'forbidden fruit' tastes the best.

Moreover, it seems that other, less intrusive methods of preventing suicide, such as preventive measures, can also be found. ${ }^{63}$ The criminalisation of suicide attempts therefore does not meet the requirement of necessity, violating the ultima ratio principle of criminal law. Its introduction would be, as K. Burdziak aptly stresses, unconstitutional and therefore unacceptable. ${ }^{64}$

\section{The freedom of a human being to decide to end his/her own existence}

The inherent and inalienable dignity of the human being requires respect for the right to end one's existence. This right is linked to the limitation of the protection

60 Malczewski, J., Problemy z prawna kwalifikacja lekarskiej pomocy do samobójstwa, "Prokuratura i Prawo" 2008, No. 11, p. 23; Wąsek, A., Prawnokarna problematyka samobójstwa, Warszawa 1981, p. 48. As M. Płatek adds, '(...) more often a suicide can count on understanding and compassion than on condemnation'. See also: Stefaniuk, M., op. cit., pp. 19, 21-22, 33-34.

61 Wąsek, A., op. cit., p. 48.

62 Pasikowski, S., Opór indywidualny. Teorie, klasyfikacje i diagnozowanie w ujęciu psychologicznym, “Teraźniejszość - Człowiek - Edukacja” 2014, No. 68, p. 43.

63 See: Burdziak, K. op. cit., p. 105. An example of such actions is the publication of a guide for employees of educational institutions, see: Szymańska, J., Zapobieganie samobójstwom dzieci i młodzieży. Poradnik dla pracowników szkót i placówek oświatowych oraz rodziców, Warszawa 2016, pp. 37.

64 See: Burdziak, K., op. cit., p. 175. 
of human life, which is an extremely precious value for society and the State. Therefore, it cannot be taken too broadly. A person who is considering a suicide attempt is always in an abnormal motivational situation because he/she wants to behave in a way that contradicts the natural self-preservation instinct. ${ }^{65}$ Therefore, such a decision must be made solely by oneself, without any influence from third parties. But, the need to respect the decision to commit suicide does not mean that it is possible to offer the suicidal person help in the attempt at suicide. ${ }^{66}$

Taking into account the above thesis, it should be pointed out that the Polish legislator when criminalising the forcing of and help with suicide attempts (Article 151 of the Criminal Code), ${ }^{67}$ stalking crimes $^{68}$ (Article 190a $\$ 3$ of the Criminal Code), abuse of a close or dependent person (Article $207 \$ 3$ of the Criminal Code), as well as the soldier's abuse on his/her subordinates (Article $352 \$ 3$ of the Criminal Code), protects first of all the freedom of a person to decide to end his/her own existence, and only then his/her life.

The above thesis is confirmed by the criminalisation of the so-called euthanasia murder (Article 150 of the Criminal Code). Although the state does not oblige a person to live, prohibiting the possibility of committing suicide, it has the right to oblige others to respect the life of another person, as its destruction is irreversible. ${ }^{69}$ The admissibility of euthanasia or helping in suicide is always at risk, to some extent, of the undesirable influence of third parties in such a unique, particularly important, and even intimate situation, which is the decision to end his/her own life. The same remark can, however, be made regarding the possibility of refusing

65 Grudecki, M., op. cit., pp. 63-64, 79; Stefaniuk, M., op. cit., p. 13.

66 As S. Kijaczko points out, 'the possibility of choice is the basic context explaining the nature of the phenomenon of suicide, included in the formula of an unforced and deliberate action, whose perpetrator, aware of its result, alone determines the circumstances, conditions and factors causing his/her death', see: Kijaczko, S., op. cit., p. 365. See also: Konieczniak, P., W sprawie eutanatycznej pomocy do samobójstwa, "Państwo i Prawo" 1999, No. 5, p. 75.

67 Act of 6 June 1998 - Criminal Code, Dz.U. (Journal of Laws) of 2019, item 1950 as amended.

68 Patrycja Kozłowska-Kalisz writes in detail about the symptom of the effect of a suicide attempt under Polish criminal law, see: Kozłowska-Kalisz, P., Targnięcie się na własne życie - wybrane zagadnienia dogmatyczne, in: Mozgawa, M. (ed.), op. cit., pp. 89-110.

69 See: Noll, P., op. cit., p. 67, 79. 
the consent for therapeutic treatments in a situation where this leads to death ${ }^{70}$. In this case, the inconsistency of the legislator is surprising and difficult to justify. ${ }^{71}$

\section{Conclusion}

Suicide is a highly negative issue, since its effects not only harm the individual who acts against his/her own life contrary to his/her natural self-preservation instinct, but also people in general. Despite this, given its nature, and above all the state of the person making such a desperate decision, it is not possible to forbid suicide attempts or to condemn suicides in an exceptional (all the more legal) way.

Therefore, both the canonical and secular legislators, when implementing legal norms for suicides, only marginally protect human life from destruction by its owner. An argument confirming this thesis is the de lege lata abandonment of the regulations of the Pio-Benedictine Code, which in genere prohibits the burial of people who deliberately took their own lives. In the case of secular law, the argument in this respect is an unquestionable ban on criminalising suicide attempts, as well as excluding them from the standard of sanction derived from Article 148 of the Criminal Code.

The main aim of the activity of church and secular legislators is therefore the protection of other goods connected with the phenomenon of suicide. As has already been mentioned, suicidal issues are currently seen in canon law mainly in the perspective of the protection of specific spiritual goods, such as the sacraments (ordination) or sacramentals (funeral), which are significantly threatened by suicide attempts. In Polish criminal law, the main object of protection is the freedom of a person to decide to end his/her existence. The legislator protects an individual from any interference by third parties in this respect.

\section{References}

Augustine of Hippo, The City of God, Kęty 2002.

Bączkowicz, F., Prawo kanoniczne. Podręcznik dla duchowieństwa. Tom. II, Opole 1958.

70 As T. Kaczmarek points out, 'axiological rigor would suggest that the law should consistently either allow or prohibit a person from freely making decisions relating to his/her private life, both if it were to concern the demand for his/her own death as well as the lack of consent for the medical treatment the initiation or continuation of which would be necessary to save his/her life', see: Kaczmarek, T., op. cit., p. 423.

71 And, as S. Kijaczko rightly points out, 'the regulations that uphold freedom cannot be inconsistent or contradictory', see: Kijaczko, S., op. cit., p. 365. 
Biblia Tysiąclecia - Pismo Święte Starego i Nowego Testamentu, Wyd. 5, Poznań 2012.

Burdziak, K., Samobójstwo w prawie polskim, Warszawa 2019.

Chmaj, M., Godność człowieka jako źródło jego wolności i praw, in: Chmaj, M. (ed.), Konstytucyjne wolności i prawa w Polsce. Tom I. Zasady ogólne, Kraków 2002.

Complak, K., O prawidłowe pojmowanie godności osoby ludzkiej w porzadku RP, in: Banaszak, B. and Preisner, A. (eds.), Prawa i wolności obywatelskie w Konstytucji RP, Warszawa 2002.

Episcopal Conference of Poland, Instrukcja liturgiczno-duszpasterska o pogrzebie i modlitwach za zmarlych, 05.05.1978, in: Obrzędy pogrzebu dostosowane do zwyczajów diecezji polskich, Katowice 2011.

Gasparri, P., Catholic Catechism, translated by Korzonkiewicz, J., Warszawa 2015.

Glaser, S., Zabójstwo na żądanie, Warszawa 1936.

Granat, M., Godność człowieka z art. 30 Konstytucji jako wartość i norma prawna, "Państwo i Prawo" 2014, No. 8.

Grudecki, M., Wybrane prawnokarne aspekty prób samobójczych, nakłaniania do samobójstwa oraz pomocy w samobójstwie, "Wojskowy Przegląd Prawniczy" 2019, No. 2.

Gubiński, A., Wyłączenie bezprawności czynu, Warszawa 1961.

Hołówka, J., Etyka w działaniu, Warszawa 2001.

Insadowski, H., Kościelne prawo pogrzebowe, Włocławek 1930.

John XXIII, Encyclical Ad Petri Cathedram, "News of the Archdiocese of Warszawa" 1960, No. 1.

John Paul II, Encyclical Evangelium vitae, Poznań 1995.

Kaczmarek, T., Wolność dysponowania życiem a prawo do godnej śmierci, in: Kaczmarek, T. (ed.), Rozważania o przestępstwie i karze. Wybór prac z okresu 40-lecia naukowej twórczości, Warszawa 2006.

Kakareko, K., Samobójstwo w różnych kulturach prawnych, in: Mozgawa, M. (ed.), Samobójstwo, Warszawa 2017.

Katechizm Kościoła Katolickiego, wyd. II, Poznań 2012.

Kijaczko, S., Konstruktywny i niekonstruktywny potencjał samobójstwa, in: Mozgawa, M. (ed.), Samobójstwo, Warszawa 2017.

Klamut, K., Aktywność obywatelska jako rodzaj aktywności społecznej-perspektywa psychologiczna, "Studia Socjologiczne" 2013, No. 1.

Konieczniak, P., W sprawie eutanatycznej pomocy do samobójstwa, "Państwo i Prawo" 1999, No. 5.

Kozłowska-Kalisz, P., Targnięcie się na własne życie - wybrane zagadnienia dogmatyczne, in: Mozgawa, M. (ed.), Samobójstwo, Warszawa 2017.

Malczewski, J., Problemy z prawną kwalifikacją lekarskiej pomocy do samobójstwa, "Prokuratura i Prawo" 2008, No. 11. 
Noll, P., Übergesetzliche Rechtfertigungsgründe im besonders die Einwilligung des Verletzten, Basel 1955.

Pasikowski, S., Opór indywidualny. Teorie, klasyfikacje i diagnozowanie w ujęciu psychologicznym, "Teraźniejszość - Człowiek - Edukacja” 2014, No 68.

Pastuszko, M., Nieprawidłowości i przeszkody do święceń (kanony 1040-1049), "Prawo Kanoniczne" 2007, No. 3/4.

Płatek, M., Prawna natura samobójstwa. Od anomii po autonomię, in: Mozgawa, M. (ed.), Samobójstwo, Warszawa 2017.

St. Thomas Aquinas, Summa theologiae, vol. 18 (Justice), translated by Bednarski, F., London 1970.

Stefaniuk, M., Samobójstwo jako zjawisko społeczne - pojęcie i rodzaje, in: Mozgawa, M. (ed.), Samobójstwo, Warszawa 2017.

Syryjczyk, J., Sankcje w Kościele, Warszawa 2008.

Szeroczyńska, M., Eutanazja i wspomagane samobójstwo na świecie. Studium prawnoporównawcze, Kraków 2004.

Sztafrowski, E., Miejsca i czasy święte, Warszawa 1970.

Szwagrzyk, T., Samobójstwo i pogrzeb kościelny, "Ruch Biblijny i Liturgiczny” 1961, No 5.

Szymańska, J., Zapobieganie samobójstwom dzieci i młodzieży. Poradnik dla pracowników szkół i placówek oświatowych oraz rodziców, Warszawa 2016.

Vatican Council II, Pastoral Constitution on the Church in the Modern World Gaudium et spes, 7.12.1965, in: Groblicki, J. and Florkowski, E. (eds.), Vatican Council II. Constitutions, edicts, declarations. Polish text, Poznań 1968, No. 76.

Walton, J.H. et al., in: Chrostowski, W. (ed.), The IVP Bible background commentary: Old Testament, Warszawa 2014.

Wąsek, A., Prawnokarna problematyka samobójstwa, Warszawa 1981.

Wolczko, M., Odmowa pogrzebu kościelnego. Zarys ewolucji historycznej i obowiązujące normy, in: Kruk, E. (ed.), Pochówek w prawie kanonicznym i świeckim, Kraków 2019.

Zoll, A., Wymiar kary w aspekcie godności człowieka, in: Godność człowieka a prawa ekonomiczne i socjalne. Księga jubileuszowa wydana w piętnasta rocznicę ustanowienia Rzecznika Praw Obywatelskich, Warszawa 2003.

CITATION

Grudecki, M., Sajkowski, M., Suicide from the joint perspective of canon law and Polish law, "Acta Iuris Stetinensis" 2020, No. 3 (Vol. 31), 23-39, DOI: 10.18276/ais.2020.31-02. 